DOI: 10.46340/eppd.2021.8.5.2

\author{
Oleksandr Cheban \\ ORCID ID: https://orcid.org/0000-0001-9197-4609 \\ Odesa Center for Nonproliferation, Ukraine
}

\title{
CORRELATION BETWEEN NEGOTIATIONS OVER IRAN NUCLEAR DEAL AND ESCALATION AT SEA IN THE FIRST HALF OF 2021
}

The article reminds that the situation around the Iranian nuclear program and regional policy remained very tense during last years. The research was conducted to try to find out why the maritime security in the Gulf region continued to deteriorate due to tension around Iran even despite the negotiations that were aimed to prevent escalation of the situation around the Iranian nuclear program that took place in the first half of 2021. The article reveals that the number of incidents at sea in the Gulf region was particularly high during the diplomatic efforts to decrease tension around Iran's nuclear program and regional policy. The paper offered a hypothesis that the escalation of situation at sea was interconnected with the negotiations to revive the nuclear deal with Iran or Joint Comprehensive Plan of Action (JCPOA). The data about sea incidents in the Gulf region was studied in the article as well as the experts' assessments of these incidents. The methods of comparative and content analysis were applied in the article to analyse and compare the attacks against the Iranian ships as well as attack against other ships that were most likely conducted by Iran. It was shown in the article that some of the dangerous attacks against the Iranian ships were most likely organized by Israel who opposes the JCPOA and might have tried to convince Iran to withdraw from negotiations on resuming this nuclear deal by provoking sea incidents. As a result of the research, it was also discovered that some other sea incidents were most likely organized by Iran, which might have tried to use these incidents to push the United States to agree with a better nuclear deal for Iran. The article concluded that Iran tried to demonstrate that despite some concessions in the nuclear field, it would continue its anti-US and anti-Israeli policy in the Middle East region, and this policy includes provoking sea incidents against the ships connected with Iran's adversaries. The article also supposes that even if Iran reaches the nuclear deal, the situation at sea would most likely remain tense. The results and conclusions of the article can be practically used for the further analysis of the maritime security in the Gulf region and its connection with the development of the Iranian nuclear program.

Keywords: Iranian nuclear program, maritime security, sea incidents, Joint Comprehensive Plan of Action (JCPOA), nuclear negotiations, attacks against the ships.

Defining the problem. The crisis over the Iranian nuclear program led to increasing tension in the Middle East region, and this tension also included the worsening maritime security in and beyond Gulf region. After US President Donald Trump withdrew the United States from the nuclear deal with Iran or Joint Comprehensive Plan of Action (JCPOA) in 2018, the number of dangerous incidents and attacks against the ships of Iran and other countries dramatically increased. Nevertheless, even after the next US president Joe Biden declared his intention to resume the JCPOA, the tension at sea remained high. Before and during the peaceful nuclear negotiations between Iran and P5+1 states (China, France, Germany, Russia, United Kingdom, and United States) in February - June 2021 the number of sea incidents was particularly high. Therefore, it is important to study why the situation at sea worsened despite diplomatic efforts and peaceful initiatives to solve the problem of Iran's nuclear program and decrease tension around this country.

The problem of studying interdependence between nuclear negotiations with Iran and sea incidents is connected with the following research questions:

- Compare the reasons and timeframe of the nuclear developments of Iran in the first half of 2021 with the sea incidents that were aimed against Iran or might have been provoked by Iran 
- Discover whether the direct connection between sea incidents and nuclear negotiations existed

- Analyse what lessons could be drawn from studying escalation at sea during the six rounds of negotiations between Iran and P5+1 in April - June 2021.

Analysis of the previous publications. The problem of the Iranian maritime policy and its connection with the Iranian nuclear strategy was considered in not so many research papers. It is worth to mention the publication of Christopher Harmer, who considered the Iranian naval and maritime strategy in his report ${ }^{1}$, which was written in 2013 but still remains relevant because the author studied the evolution of the Iranian navy and commercial fleet and correctly defined the trends of their development that still take place. Kenneth Katzman, Neelesh Nerurkar and their co-authors in their report for the US Congress, which was prepared in 2012, considered Iran's threat to the Strait of Hormuz ${ }^{2}$ and also studied the influence of the situation around Iran's nuclear program on its naval and maritime strategy. Another aspect of the maritime security in the Gulf region, which is not discussed in detail in the academic literature, is considered in the commentary of Edgar Tam, former Iran country director in the US Office of the Secretary of Defense, and Pierre Morcos, former deputy head of the Strategic Affairs and Cybersecurity Division in the French foreign service ${ }^{3}$. These authors discuss the efficiency of two international coalitions to secure the navigation in the Strait of Hormuz - the US-led International Maritime Security Construct, also known as Operation Sentinel, and European Maritime Awareness in the Strait of Hormuz, or Operation Agenor. Different aspects of the Iranian maritime and naval strategy are discussed in the analytical report ${ }^{4}$ of Farzin Nadimi, associate fellow of the Washington Institute for Near East Policy. In this research paper, the author focuses mostly on discussing the military aspects of the Iranian naval strategy, but also in some chapters of his work considers legal and security dimensions of the commercial vessels' navigation in the Persian Gulf.

The objective of this article is to study how the negotiations on resuming Iran nuclear deal affected the escalation in the Persian Gulf and other seas, and how the sea incidents with possible or confirmed Iran's involvement could influence the nuclear negotiations.

Methodology. The method of comparative analysis was used in the article to analyse the connection between sea incidents and nuclear negotiation with Iran. The method of content analysis was used to study the political statements and experts' assessments related to the possible Iran's involvement into sea incidents.

The hypothesis of this article is that the Iranian nuclear policy and maritime strategy are connected, and Iran's adversaries also sometimes try to influence the situation around Iran's nuclear program by provoking incidents against the Iranian ships. Iran may also have responded by attacking the commercial or military ships of other countries to revenge for attacks against the Iranian nuclear facilities or other important targets, although Iran often does not admit its responsibility for provoking sea incidents, unless the foreign ships are not seized and kept in Iran.

The main material. The beginning of the presidential term of US President Joe Biden in January 2021 was connected with the expectations of resuming US participation in JCPOA and decreasing tension around Iran. The previous US President Donald Trump imposed strict economic sanctions on Iran in 2018, although Iran fulfilled its obligations under JCPOA until 20195. However, after the unilateral US withdrawal from JCPOA and imposing sanctions, Iran decided to respond by gradual reducing of its participation in the nuclear deal. In 2019 - 2021, Iran was increasing the levels and scope of uranium

\footnotetext{
${ }^{1}$ Harmer, C. (2013). Iranian Naval and Maritime Strategy. Washington DC: Institute for the Study of War. <https://www.jstor.org/stable/resrep07898?seq=6\#metadata_info_tab_contents> (2021, September, 25).

${ }^{2}$ Katzman, K., Nerurkar, N. (2012). Iran's Threat to the Strait of Hormuz. Congressional Research Service <https://fas.org/sgp/crs/mideast/R42335.pdf> (2021, September, 25).

3 Tam, E., Morcos, P. (2021). Building Maritime Security Coalitions - Lessons Learned from The Strait of Hormuz. War on the Rocks, June 14. <https://warontherocks.com/2021/06/building-maritime-security-coalitions-lessonslearned-from-the-strait-of-hormuz/> (2021, September, 25).

${ }^{4}$ Nadimi, F. (2020). Iran's Evolving Approach to Asymmetric Naval Warfare: Strategy and Capabilities in the Persian Gulf. Washington Institute, April 24. <https://www.washingtoninstitute.org/media/591?disposition=inline> (2021, September, 25).

${ }^{5}$ Radio Free Europe. Radio Liberty (2019). IAEA Report Says Iran Continues to Comply with Nuclear Deal <https://www.rferl.org/a/iaea-report-says-iran-continues-to-comply-with-nuclear-deal/29974795.html> (2021, September, 25).
} 
enrichment and decreasing its cooperation with the International Atomic Energy Agency (IAEA) ${ }^{1}$ in order to convince the United States to lift the economic sanctions or make the European allies of the United States to support Iran despite the US sanctions².

While the situation around the Iranian nuclear program worsened, the regional and maritime security also deteriorated. In particular, the number of suspicious sea incidents near the Persian Gulf and in other seas dramatically increased. It seems that the escalation of the situation at sea in the Middle East region and beyond was often connected with the Iranian nuclear developments, as it will be demonstrated below.

Despite diplomatic efforts to solve the problem of the Iranian nuclear program and other security challenges related to Tehran's regime, the situation at sea remained very tense in the first half of 2021. For example, on 26 February 2021, Israeli-owned cargo ship "Helios Ray" was damaged by two limpet mines in the Gulf of Oman, and Israeli Prime Minister Benjamin Netanyahu blamed Iran for the attack, although Tehran denied its responsibility ${ }^{3}$. Just two weeks later, on 10 March 2021, Iranian container ship "Shahr-e Kord" was hit by an explosive object about 50 miles off the Israeli coast, and Israel was suspected in arranging attack against this Iranian ship ${ }^{4}$. Other two weeks later, on 25 March 2021, Israeliowned cargo ship "Lori" was struck by a missile in the Arabian Sea, and Iran was believed to be behind this missile attack ${ }^{5}$. During all these incidents, there were no casualties, but they led to increasing tension in Iran-Israeli relations.

Thus, three attacks against the commercial ships happened in the Gulf region during one month only (February - March 2021). Interestingly, this period was also marked by significant diplomatic efforts to solve the problem of the Iranian nuclear program. On 21 February 2021, the IAEA and Iran signed a technical agreement that allowed to the IAEA inspectors to have access to the cameras at the Iranian nuclear facilities ${ }^{6}$ even despite previous Iran's decision to refuse from its JCPOA commitment to provide a full access to its facilities for the IAEA ${ }^{7}$.

The technical agreement between Iran and IAEA created a possibility to prepare the direct negotiations between Iran and P4+1 (China, France, Germany, Russia, and United Kingdom) and indirect talks between Iran and USA to resume their full compliance with the JCPOA. These talks finally started in April 2021, and the aforementioned three incidents at sea during February - March 2021, could create difficulties for the restart of those talks.

The interconnection between the attacks against the ships and nuclear negotiations became even more obvious, after these talks began and continued in April - June 2021. Exactly on the same day when the nuclear talks with Iran started in Vienna (on 6 April 2021) ${ }^{8}$, the Iranian ship "Saviz" was damaged by a mine planted on its hull in the Red Sea near Djibouti". It seems that the Iranian ship was damaged

\footnotetext{
${ }^{1}$ Metzler, K., Rising, D. (2020). UN agency: Iran violating all restrictions of nuclear deal. Associated Press, June 5. <https://apnews.com/article/europe-united-nations-ap-top-news-international-news-iran-8a87a9dff7faae6b54461d5541e78bd0> (2021, September, 25).

${ }^{2}$ Wintour, P. (2019). Iran breaks nuclear deal and puts pressure on EU over sanctions. The Guardian, July 1. <https://www.theguardian.com/world/2019/jul/01/iran-breaks-nuclear-deal-and-puts-pressure-on-eu-over-sanctions> (2021, September, 25).

${ }^{3}$ Iran Primer (2021). Israel-Iran Conflict at Sea <https://iranprimer.usip.org/blog/2021/apr/14/israel-iran-conflict-sea> (2021, September, 25).

${ }^{4}$ Reuters (2021). Iranian ship hit in attack in Mediterranean, company says <https://www.reuters.com/article/ iran-ship-int-idUSKBN2B41SC> (2021, September, 25).

${ }^{5}$ Iran Primer (2021). Israel-Iran Conflict at Sea <https://iranprimer.usip.org/blog/2021/apr/14/israel-iran-conflict-sea> (2021, September, 25).

${ }^{6}$ US News (2021). IAEA Strikes Deal with Iran to Cushion Coming Blow of Slashed Access.

<https://www.usnews.com/news/world/articles/2021-02-21/iaea-chief-says-struck-deal-with-iran-to-mitigate-itcutting-cooperation> (2021, September, 25).

${ }^{7}$ Murphy, F. (2021). Iran tells IAEA it plans to scale back cooperation in a week. Reuters, February 16. <https://www.reuters.com/article/us-iran-nuclear-iaea-iduskbn2ag2hg> (2021, September, 25).

${ }^{8}$ Motamedi, M. (2021). Iran says initial nuclear talks with world powers 'constructive'. Al Jazeera, April 6. <https://www.aljazeera.com/news/2021/4/6/vienna-talks-iran-and-world-powers-begin-nuclear-negotiations> (2021, September, 25).

${ }^{9}$ Gambrell, J. (2021). Iran ship said to be Red Sea troop base off Yemen attacked. Associated Press, April 7. $<$ https://apnews.com/article/dubai-iran-united-arab-emirates-persian-gulf-tensions-yemen-9c89b8a5571468f1f12be535e8825212> (2021, September, 25).
} 
by Israel, which strongly opposed resuming the $\mathrm{JCPOA}^{1}$ and which might have been interested to provoke Iran to stop its participation in negotiations with $\mathrm{P} 5+1$ states in Vienna.

On 13 April 2021, a missile or an unmanned drone hit the Israeli-owned cargo ship "Hyperion Ray" near the port of Fujairah in the United Arab Emirates ${ }^{2}$. This attack can be considered as Iran's response on a devastating cyber-attack against the main Iranian uranium enrichment facility in Natanz that was conducted presumably by Israel two days earlier (on 11 April 2021) ${ }^{3}$.

On 26 April 2021another dangerous sea incident with confirmed Iran's participation took place. The fast attack boats of the Islamic Revolution Guard Corps Navy (IRGCN) came dangerously close (less than $100 \mathrm{~m}$ ) to the US patrol ship near the Strait of $\mathrm{Hormuz}^{4}$, and the US ship fired warning shots to avoid collision $^{5}$. This was the first time since 2017 when the US ship had to fire warning shots at the Iranian boats. Thus, this incident reflected the growing tension at sea and in the entire Gulf region. And again, like the previously mentioned cases, the incident with the warning shots happened almost immediately after an important event that was connected with the Iranian nuclear policy. Just one day before dangerous manoeuvres of the Iranian boats close to the US ship, the mass media received the leakage of interview of the Iranian foreign affairs minister Javad Zarif, which was not intended to be published soon. In this leaked interview, the Iranian official from relatively moderate government of President Hassan Rouhani criticized the Iranian ultraconservative institutions like Islamic Revolution Guard Corps (IRGC), which, according to Zarif's leaked interview, created obstacles for government's efforts to resume the nuclear deal and improve Iran's relations with the western powers ${ }^{6}$. The dangerous manoeuvres of the IRGC boats on next day after publishing scandal Zarif's interview looked like a confirmation of his critics of the Iranian hardliners camp. It seems that it was not a coincidence that the leakage of Zarif's interview to the press and dangerous manoeuvres of the IRGCN fast boats happened almost at the same time. Perhaps, in such a way the Iranian hardliners who dominated the Iranian politics wanted to send a message to the international community that Iran would be ready to make concessions in the nuclear field only but not in the regional policy issues.

A similar incident with the dangerous manoeuvres of the Iranian speed boats close to the US ship happened on 10 May 2021, and this time the US coast guards fired warning shots again to avoid collision ${ }^{7}$. This incident happened in the middle of the difficult talks over resuming JCPOA and could also damage the negotiation process.

On 2 June 2021 another dangerous incident happened, which might also have been organized to disrupt Iran's nuclear negotiations with the P5+1 powers. On this day, the biggest Iranian ship "Kharg" faced fire and sunk near the Iranian port of Jask despite the efforts of the Iranian forces to save it. Few crew members were injured but no casualties were reported. It was suspected that the ship was heavily damaged by the Israeli attack although Israel did not confirm its participation in this incident ${ }^{8}$.

\footnotetext{
${ }^{1}$ Bredemeier, K. (2021). Israel Voices Opposition to Revamped Iran Nuclear Deal. Voice of America, June 27. <https://www.voanews.com/a/middle-east_israel-voices-opposition-revamped-iran-nuclear-deal/6207542.html> (2021, September, 25).

${ }^{2}$ Times of Israel (2021, April 13). Israeli-owned ship said attacked off UAE coast amid sky-high tensions with Iran. <https://www.timesofisrael.com/israeli-owned-ship-said-attacked-off-uae-coast-amid-sky-high-tensions-with-iran/> (2021, September, 25).

${ }^{3}$ Hafezi, P. (2021). Iran says Natanz nuclear site hit by terrorism - TV. Reuters, April 11.

$<$ https://www.reuters.com/world/middle-east/iran-reports-incident-natanz-nuclear-site-no-casualties-press-tv-2021-04-11/> (2021, September, 25).

${ }^{4}$ Gambrell, J. (2021). US Navy fires warning shots in new tense encounter with Iran. Associated Press. <https://apnews.com/article/iran-government-and-politics-persian-gulf-tensions-middle-east-cc139f729c3b6a3b2ef6989a91b70ff3> (2021, September, 25).

${ }^{5}$ Iran Primer (2021). Timeline: U.S.-Iran Naval Encounters <https://iranprimer.usip.org/blog/2021/may/05/ timeline-us-iran-naval-encounters $>$ (2021, September, 25).

${ }^{6}$ Hafezi, H., Maclean, W. (2021). In leaked recording, Iran's Zarif criticises Guards' influence in diplomacy. Reuters, April 26. <https://www.reuters.com/world/middle-east/leaked-recording-irans-zarif-criticises-guardsinfluence-diplomacy-2021-04-26/> (2021, September, 25).

${ }^{7}$ Ali, I., Stewart, Ph. (2021). U.S. military ship fires 30 warning shots after encounter with Iranian vessels. Reuters, May 10. <https://www.reuters.com/world/us-military-ship-fires-30-warning-shots-after-encounter-withiranian-vessels-2021-05-10/> (2021, September, 25).

${ }^{8}$ Vahdat, A., Gambrell, J. (2021). Largest ship in Iranian navy catches fire and sinks. Times of Israel, June 2. <https://www.timesofisrael.com/largest-ship-in-iranian-navy-catches-fire-and-sinks/> (2021, September, 25).
} 
Iran responded on this incident by the manoeuvres of its naval warship "Makran" and support vessel in the Atlantic Ocean in June 2021. During few weeks, it was speculated that the Iranian warships were heading to Venezuela to deliver weapons to this country, which remains one of the few friendly states to the Iranian regime in the world ${ }^{1}$. The expected arrival of the Iranian warships to Venezuela caused tension and threatened the nuclear negotiations with Tehran. One year before, in 2020, the United States had already seized the ships heading from Iran to Venezuela to prevent oil delivery from Iran to Venezuela (both countries are under US economic sanctions) ${ }^{2}$. However, that incident involved the commercial ships that were not even owned by Iran. The delivery of weapons from Iran to Venezuela would be much more dangerous for the US interests than the oil trade between these two countries, and therefore, the United States expressed their serious concern ${ }^{3}$. However, this time the United States would have to deal with the Iranian warships. If the United States tried to prevent their arrival to Venezuela, a military conflict between Iran and the United States could have started, not to say about potential disruption of the negotiation process to revive the JCPOA. In addition, as the US experts discussed, from the legal point of view, the United States would not be allowed to take any action against the Iranian ships ${ }^{4}$. Despite the possible catastrophic consequences of the potential interaction with the Iranian ships in the Atlantic, some hardliner politicians pressed the President Joe Biden's administration, demanding to "forcefully" stop the Iranian warships in case they approach Venezuela ${ }^{5}$.

However, the potential escalation did not happen because at the end the Iranian ships never arrived at Venezuela but headed to Russia's Saint Petersburg to participate in celebrating the Russian Navy's Day at the end of July $2021^{6}$. Nevertheless, Iran demonstrated that its warships were able to do long voyages and challenge the US interests in Atlantic. At the same time, Iran did not want to escalate situation at sea too much and damage nuclear negotiations, and for this reason, it might have decided not to send its warships to Venezuela.

Thus, during February - June 2021, a number of the dangerous incidents at sea happened. Some of these incidents can be considered like a possible response to the previous attacks (for example, in response for attacking the nuclear facility in Natanz, Iran might have damaged the Israeli-owned ship "Hyperion Ray" in April 2021). Some other incidents can be considered as attempts to damage the negotiation process to resume the JCPOA, like the attack against the Iranian ship "Saviz" that happened on the first day of the nuclear negotiations in April 2021.

Nevertheless, despite the highly provocative attacks against the Iranian ships, including sinking Iran's largest warship, the negotiations to revive the JCPOA continued. Only in June 2021, Iran decided to suspend these nuclear negotiations ${ }^{7}$. However, the main reason for this Iran's suspending of negotiations were not provocations at sea or attacks against Iranian nuclear facilities that were most likely organized by Israel, which opposes JCPOA's restoration. It seems Iran planned the suspension of the nuclear negotiations for the long time, and for this reason, Iran might have organized some provocations at sea to check the reaction of the western powers.

\footnotetext{
${ }^{1}$ Debre, I., Gambrell, J. (2021). Iran sends warships to Atlantic amid Venezuela concerns. Associated Press, June 10. <https://apnews.com/article/middle-east-iran-10b8da94fa9040ec6348a7b7006d879b> (2021, September, 25).

${ }^{2}$ Neuman, S. (2020). U.S. Seizes Iranian Fuel From 4 Tankers Bound for Venezuela. NPR, August 14. <https://www.npr.org/2020/08/14/902532689/u-s-seizes-iranian-fuel-from-4-tankers-bound-for-venezuela> (2021, September, 25).

${ }^{3}$ Bab, C. (2021). Iranian Naval Passage Through Atlantic Prompts US Concern. Voice of America, June 25. $<$ https://www.voanews.com/a/middle-east_voa-news-iran_iranian-naval-passage-through-atlantic-prompts-us-concern/ 6207470.html> (2021, September, 25).

${ }^{4}$ Overfield, C. (2021). Why the United States Can’t Touch Iran's Atlantic-Bound Warships. Foreign Policy, June 10. <https://foreignpolicy.com/2021/06/10/venezuela-sanctions-iran-warships-law/> (2021, September, 25)

${ }^{5}$ Jenkins, C. (2021). Rubio calls on Biden to 'forcefully' confront Iran over movement of war ships. The Hill, 12 June. <https://thehill.com/homenews/senate/558117-rubio-calls-on-biden-to-forcefully-confront-iran-over-movement-of-war-ships> (2021, September, 25).

${ }^{6}$ Liebermann, O., Kaufman, E. (2021). Iranian ships that appeared headed for Venezuela are now in Baltic Sea approaching Russia. CNN, July 22. 〈https://edition.cnn.com/2021/07/22/politics/iran-ships-baltic/index.html> (2021, September, 25).

${ }^{7}$ Mohammed, A. (2021). Exclusive: Iran not ready for nuclear talks until Raisi takes over. Reuters, July 15. $<\mathrm{https}: / /$ www.reuters.com/world/middle-east/exclusive-iran-not-ready-nuclear-talks-until-raisi-takes-over-source-2021-07-14/> (2021, September, 25).
} 
The officially proclaimed reason of Iran's decision to suspend the talks on resuming JCPOA was the presidential election in June 2021. Iran asked other negotiating parties to wait several months until the new elected president Ebrahim Raisi enters the office and forms the new government ${ }^{1}$. However, it is well known that the president in Iran has not so much power because the key decisions of Iran's foreign and nuclear policy are made by the Supreme Leader Ayatollah Ali Khamenei ${ }^{2}$. It seems that Ali Khamenei chose the presidential election as a convenient reason to shift Iran's policy to more hardliners approach. Therefore, Iran might have provoked some sea incidents (like dangerous manoeuvres in April - May 2021 close to the US ships) to demonstrate that it was not going to make too many concessions to the western powers.

Another reason why Iran provoked some dangerous sea incidents exactly during the nuclear negotiations can be connected with Tehran's wish to press Washington to agree with a better deal for Iran. Moreover, Iran was aware that the United States did not want to enter military confrontation with it, and for this reason it might have felt that its sea provocation would not be punished ${ }^{3}$. Nevertheless, as it was already mentioned, Iran did not take too provocative actions like expected sending of weapons to Venezuela by sea.

After suspending nuclear negotiations in June 2021, the situation at sea in the Gulf region remained tense. On 30 July 2021, Israeli-managed petroleum product tanker "Mercer Street" was attacked by the drone near the coast of Oman and two crew members were killed ${ }^{4}$. Iran was suspected in launching this attack as well as in attempt to hijack the Panama-flagged ship "Asphalt Princess" few days later. On 3 August 2021, the armed men boarded "Asphalt Princess" and tried to divert it to Iran but failed because the crew sabotaged the engine, and soon the US and Omani warships arrived at the scene, so the hijackers had to escape ${ }^{5}$.

Although Iran did not admit its responsibility in provoking these two incidents at sea, they may demonstrate once again that Iran does not hurry to resume the nuclear deal. It seems that at the moment Iran may understand that lifting US economic sanctions in conditions of pandemic depression would not benefit too much to the Iranian economy ${ }^{6}$. Perhaps, for this reason, Iran did not worry too much that the sea provocations could have damaged its nuclear negotiations with the western countries.

Some important lessons could be learned from the escalation of tension at sea during the nuclear negotiations. Iran demonstrated again that its willingness to make some concessions in the nuclear field does not necessarily mean its readiness to reduce tension in relations with its adversaries, and this tension continued to be reflected in the sea incidents.

Conclusions. It can be concluded that the hypothesis of this article is confirmed and the nuclear negotiations and escalation at sea are most likely interconnected. The number of sea incidents increased before and during the negotiations to resume the JCPOA, one incident even happened on the first day of the negotiations. The attacks targeted the Iranian commercial and military ships and were most likely aimed at discouraging Iran to participate in the nuclear negotiations.

At the same time, Iran also provoked a number of incidents during the nuclear talks, and those incidents could have disrupted the negotiation process too. Iran's willingness to conduct sea provocations

\footnotetext{
${ }^{1}$ Times of Israel (2021, July 17). Iran nuclear negotiator: Vienna talks must wait for new president to take office. <https://www.timesofisrael.com/iran-nuclear-negotiator-vienna-talks-must-wait-for-new-president-to-take-office/> (2021, September, 25).

${ }^{2}$ Gladstone, R. (2021). Is Iran's Supreme Leader Truly Supreme? Yes, but President Is No Mere Figurehead. The New York Times, August 5. <https://www.nytimes.com/2021/08/05/world/middleeast/iran-president-ebrahim-raisi.html> (2021, September, 25).

${ }^{3}$ Gewirtz, J., Domm, P. (2021). Incident with multiple tankers in Gulf of Oman raises concerns in oil market. CNBC, August 3. <https://www.cnbc.com/2021/08/03/incident-with-multiple-tankers-in-gulf-of-oman-raisesconcerns-in-oil-market.html> (2021, September, 25).

${ }^{4}$ Barrington, L., Saul, J., Williams, D. (2021). Israel blames Iran for attack on tanker off Oman that killed two. Reuters, July 31. <https://www.reuters.com/world/middle-east/ukmto-says-received-reports-vessel-attackedoff-oman-coast-2021-07-30/> (2021, September, 25).

${ }^{5}$ Marine Insight (2021). Crew Of Tanker 'Asphalt Princess' Prevents Hijack by Sabotaging Its Engine. $<$ https://www.marineinsight.com/shipping-news/crew-of-tanker-asphalt-princess-prevents-hijack-by-sabotaging-its-engine/> (2021, September, 25).

${ }^{6}$ Khoshnood, A. (2021). The Dangers of Lifting Sanctions on the Islamic Regime of Iran. Besa Center, January 28. <https://besacenter.org/lifting-iran-sanctions/> (2021, September, 25).
} 
might have been caused by possible Iran's belief that the United States could be pressed to approve a better deal with Iran and that Washington would unlikely punish Tehran for dangerous sea provocations. Moreover, the complicated economic situation during pandemic reduces the attractiveness of lifting US economic sanctions for Iran, and that could be one more reason why Iran did not worry too much about possible damage for the nuclear talks that could be done by the Iranian sea provocations.

Thus, for different reasons, the nuclear negotiations did not lead to de-escalation at sea but even contributed to the growing tension. Actually, the negotiations still need to be continued, and the absence of the clear prospective of resuming the nuclear deal with Iran creates uncertainty and decreases the regional security, including in the maritime domain. However, as the logic of Iran's current hard-line policy demonstrated, even the restoration of the JCPOA could be not enough for de-escalation of tension at sea in the Gulf region and beyond.

\section{References:}

1. Ali, I., Stewart, Ph. (2021). U.S. military ship fires 30 warning shots after encounter with Iranian vessels. Reuters, May 10. <https://www.reuters.com/world/us-military-ship-fires-30-warning-shots-after-encounterwith-iranian-vessels-2021-05-10/> (2021, September, 25). [in English].

2. Bab, C. (2021). Iranian Naval Passage Through Atlantic Prompts US Concern. Voice of America, June 25. $<$ https://www.voanews.com/a/middle-east_voa-news-iran_iranian-naval-passage-through-atlantic-promptsus-concern/6207470.html> (2021, September, 25). [in English].

3. Barrington, L., Saul, J., Williams, D. (2021). Israel blames Iran for attack on tanker off Oman that killed two. Reuters, July 31. <https://www.reuters.com/world/middle-east/ukmto-says-received-reports-vessel-attackedoff-oman-coast-2021-07-30/> (2021, September, 25). [in English].

4. Bredemeier, K. (2021). Israel Voices Opposition to Revamped Iran Nuclear Deal. Voice of America, June 27. $\langle$ https://www.voanews.com/a/middle-east_israel-voices-opposition-revamped-iran-nuclear-deal/6207542.html> (2021, September, 25). [in English].

5. Debre, I., Gambrell, J. (2021). Iran sends warships to Atlantic amid Venezuela concerns. Associated Press, June 10. <https://apnews.com/article/middle-east-iran-10b8da94fa9040ec6348a7b7006d879b> (2021, September, 25). [in English].

6. Gambrell, J. (2021). Iran ship said to be Red Sea troop base off Yemen attacked. Associated Press, April 7. <https://apnews.com/article/dubai-iran-united-arab-emirates-persian-gulf-tensions-yemen-9c89b8a55714 68f1f12be535e8825212> (2021, September, 25). [in English].

7. Gambrell, J. (2021, April 28). US Navy fires warning shots in new tense encounter with Iran. Associated Press. $<\mathrm{https} / / /$ apnews.com/article/iran-government-and-politics-persian-gulf-tensions-middle-east-cc139f729c3b6a3b 2ef6989a91b70ff3> (2021, September, 25). [in English].

8. Gewirtz, J., Domm, P. (2021). Incident with multiple tankers in Gulf of Oman raises concerns in oil market. CNBC, August 3. <https://www.cnbc.com/2021/08/03/incident-with-multiple-tankers-in-gulf-of-oman-raisesconcerns-in-oil-market.html> (2021, September, 25). [in English].

9. Gladstone, R. (2021). Is Iran's Supreme Leader Truly Supreme? Yes, but President Is No Mere Figurehead. The New York Times, August 5. <https://www.nytimes.com/2021/08/05/world/middleeast/iran-presidentebrahim-raisi.html> (2021, September, 25). [in English].

10. Hafezi, H., Maclean, W. (2021). In leaked recording, Iran's Zarif criticises Guards' influence in diplomacy. Reuters, April 26. <https://www.reuters.com/world/middle-east/leaked-recording-irans-zarif-criticises-guardsinfluence-diplomacy-2021-04-26/> (2021, September, 25). [in English].

11. Hafezi, P. (2021). Iran says Natanz nuclear site hit by terrorism - TV. Reuters, April 11. $<$ https://www.reuters.com/world/middle-east/iran-reports-incident-natanz-nuclear-site-no-casualties-press-tv-2021-04-11/> (2021, September, 25). [in English].

12. Harmer, C. (2013). Iranian Naval and Maritime Strategy. Washington DC: Institute for the Study of War. 38 p. $<$ https://www.jstor.org/stable/resrep07898?seq=6\#metadata_info_tab_contents> (2021, September, 25). [in English].

13. Iran Primer (2021). Israel-Iran Conflict at Sea. <https://iranprimer.usip.org/blog/2021/apr/14/israel-iran-conflict-sea〉 (2021, September, 25). [in English].

14. Iran Primer (2021). Timeline: U.S.-Iran Naval Encounters. <https://iranprimer.usip.org/blog/2021/may/05/ timeline-us-iran-naval-encounters> (2021, September, 25). [in English].

15. Jenkins, C. (2021). Rubio calls on Biden to 'forcefully' confront Iran over movement of war ships. The Hill, 12 June. $<$ https://thehill.com/homenews/senate/558117-rubio-calls-on-biden-to-forcefully-confront-iran-over-movementof-war-ships> (2021, September, 25). [in English].

16. Katzman, K., Nerurkar, N. (2012). Iran's Threat to the Strait of Hormuz. Congressional Research Service. <https://fas.org/sgp/crs/mideast/R42335.pdf> (2021, September, 25). [in English].

17. Khoshnood, A. (2021). The Dangers of Lifting Sanctions on the Islamic Regime of Iran. Besa Center, January 28. $<$ https://besacenter.org/lifting-iran-sanctions/> (2021, September, 25). [in English]. 
18. Liebermann, O., Kaufman, E. (2021). Iranian ships that appeared headed for Venezuela are now in Baltic Sea approaching Russia. CNN, July 22. <https://edition.cnn.com/2021/07/22/politics/iran-ships-baltic/index.html> (2021, September, 25). [in English].

19. Marine Insight (2021). Crew Of Tanker 'Asphalt Princess' Prevents Hijack by Sabotaging Its Engine. $<$ https://www.marineinsight.com/shipping-news/crew-of-tanker-asphalt-princess-prevents-hijack-by-sabotagingits-engine/> (2021, September, 25). [in English].

20. Metzler, K., Rising, D. (2020). UN agency: Iran violating all restrictions of nuclear deal. Associated Press, June 5. $<$ https://apnews.com/article/europe-united-nations-ap-top-news-international-news-iran-8a87a9dff7faae6b 54461d5541e78bd0> (2021, September, 25). [in English].

21. Mohammed, A. (2021). Exclusive: Iran not ready for nuclear talks until Raisi takes over. Reuters, July 15. <https://www.reuters.com/world/middle-east/exclusive-iran-not-ready-nuclear-talks-until-raisi-takes-over-source2021-07-14/> (2021, September, 25). [in English].

22. Motamedi, M. (2021). Iran says initial nuclear talks with world powers 'constructive'. Al Jazeera, April 6. <https://www.aljazeera.com/news/2021/4/6/vienna-talks-iran-and-world-powers-begin-nuclear-negotiations> (2021, September, 25). [in English].

23. Murphy, F. (2021). Iran tells IAEA it plans to scale back cooperation in a week. Reuters, February 16. <https://www.reuters.com/article/us-iran-nuclear-iaea-iduskbn2ag2hg> (2021, September, 25). [in English].

24. Nadimi, F. (2020). Iran's Evolving Approach to Asymmetric Naval Warfare: Strategy and Capabilities in the Persian Gulf. Washington Institute, April 24. <https://www.washingtoninstitute.org/media/591?disposition=inline> (2021, September, 25). [in English].

25. Neuman, S. (2020). U.S. Seizes Iranian Fuel From 4 Tankers Bound for Venezuela. NPR, August 14. <https://www.npr.org/2020/08/14/902532689/u-s-seizes-iranian-fuel-from-4-tankers-bound-for-venezuela> (2021, September, 25). [in English].

26. Overfield, C. (2021). Why the United States Can't Touch Iran's Atlantic-Bound Warships. Foreign Policy, June 10. <https://foreignpolicy.com/2021/06/10/venezuela-sanctions-iran-warships-law/> (2021, September, 25). [in English].

27. Radio Free Europe. Radio Liberty (2019). IAEA Report Says Iran Continues to Comply with Nuclear Deal. <https://www.rferl.org/a/iaea-report-says-iran-continues-to-comply-with-nuclear-deal/29974795.html> (2021, September, 25). [in English].

28. Reuters (2021). Iranian ship hit in attack in Mediterranean, company says <https://www.reuters.com/article/ iran-ship-int-idUSKBN2B41SC> (2021, September, 25). [in English].

29. Tam, E., Morcos, P. (2021). Building Maritime Security Coalitions - Lessons Learned from The Strait of Hormuz. War on the Rocks, June 14. <https://warontherocks.com/2021/06/building-maritime-security-coalitions-lessonslearned-from-the-strait-of-hormuz/> (2021, September, 25). [in English].

30. Times of Israel (2021, April 13). Israeli-owned ship said attacked off UAE coast amid sky-high tensions with Iran. <https://www.timesofisrael.com/israeli-owned-ship-said-attacked-off-uae-coast-amid-sky-high-tensions-with-iran/> (2021, September, 25). [in English].

31. Times of Israel (2021, July 17). Iran nuclear negotiator: Vienna talks must wait for new president to take office. <https://www.timesofisrael.com/iran-nuclear-negotiator-vienna-talks-must-wait-for-new-president-to-take-office/> (2021, September, 25). [in English].

32. US News (2021). IAEA Strikes Deal with Iran to Cushion Coming Blow of Slashed Access. $<$ https://www.usnews.com/news/world/articles/2021-02-21/iaea-chief-says-struck-deal-with-iran-to-mitigateit-cutting-cooperation> (2021, September, 25). [in English].

33. Vahdat, A., Gambrell, J. (2021). Largest ship in Iranian navy catches fire and sinks. Times of Israel, June 2. $<$ https://www.timesofisrael.com/largest-ship-in-iranian-navy-catches-fire-and-sinks/> (2021, September, 25). [in English].

34. Wintour, P. (2019). Iran breaks nuclear deal and puts pressure on EU over sanctions. The Guardian, July 1. <https://www.theguardian.com/world/2019/jul/01/iran-breaks-nuclear-deal-and-puts-pressure-on-eu-over-sanctions> (2021, September, 25). [in English]. 